\title{
SUPERVISED PHYSICAL TRAINING IMPROVES FINE MOTOR SKILLS OF 5-YEAR-OLD CHILDREN
}

\author{
O TREINAMENTO FISICOSUPERVISIONADO MELHORA AS HABILIDADES MOTORAS FINAS \\ EMCRIANÇASDE 5 ANOS \\ EL ENTRENAMIENTO FÍSICO SUPERVISADO MEJORA LAS HABILIDADES MOTORAS FINAS \\ EN NIÑOS DE CINCO AÑOS
}

Original Article

Artigo OrIGINAL

Artículo Original

\begin{abstract}
Yugang Qi (Teacher)
Sijie $\operatorname{Tan}^{2}$ (Teacher)

Mingyang Sui² (Lecturer)

Jianxiong Wang ${ }^{3}$ (Senior Lecturer)

1. Tianjin University of Science and Technology, Department of Physical Education, China.

2. Tianjin University of Sport, Tianjin Physical Fitness Research Center, Department of Health and Exercise Science, China.

3. University of Southern

Queensland, School of Health and Wellbeing, Australia.
\end{abstract}

\section{Correspondence: \\ Jianxiong Wang \\ School of Health and Wellbeing, Faculty of Health, Engineering, and Sciences, University of Southern Queensland, Toowoomba QLD 4350, Australia. wangj@usq.edu.au}

\begin{abstract}
Introduction: Fine motor skills are important for children not only in the activities of daily living, but also for learning activities. In the present study, the effects of supervised physical training were investigated in normal children. Objective: To evaluate the effects of supervised training by combining full-body exercise and the eye-hand coordination activities to improve fine motor skills in a group of five-year-old normal children. Methods: Fifty-two children were selected and randomized in exercise and control groups. The exercise group participated in three 30-minute training sessions per week for 24 weeks. Results: The fine motor skills and hand grip strength of the exercise group were significantly increased, while there was no significant change in the control group during the experimental period. Conclusion: The results indicate that the current exercise training program is effective and can be applied to 5-year-old normal children to improve their fine motor skills. In addition, this program has simple physical activities that are appropriate to the physical and mental level of child development. The 30-minute training session would be easily implemented in the kindergarten program. Level of Evidence l; High quality randomized trial with statistically significant difference or no statistically significant difference but narrow confidence intervals.
\end{abstract}

Keywords: Physical training; Motor skills; Child.

\section{RESUMO}

Introdução: As habilidades motoras finas são importantes para as crianças, não sónas atividades davida diária, mas também nas atividades de aprendizado. No presenteestudo, os efeitos do treinamento físico supervisionado foram investigados em crianças normais. Objetivo: Avaliar os efeitos do treinamento supervisionado, combinando o exercício de corpo inteiro e as atividades de coordenação olho-mão para melhorar as habilidades motoras finas em um grupo de crianças normais de cinco anos de idade. Métodos: Cinquenta e duas crianças foram selecionadas e randomizadas em grupos de exercício e controle. O grupo exercício participou de três sessões de treino de 30 minutos por semana durante 24 semanas. Resultados: As habilidades motoras finas e a força de preensão manual do grupo exercício aumentaram significativamente, enquanto não houve alteração significativa no grupo controle durante o período experimental. Conclusão: Os resultados indicam que o programa de treinamento atualéefetivo e pode ser aplicado a crianças normais de cinco anos de idade para melhorar suas habilidades motoras finas. Além disso, este programa tem atividades físicas simples que são adequadas a n nivel físico emental de desenvolvimento infantil. A sessão de treino de 30 minutos seriafacilmente implementada no programa dojardim da infância. Nível de Evidência l; Estudos clínicos randomizado de alta qualidade com ou sem diferença estatisticamente significante, mas com intervalos de confiança estreitos.

Descritores: Treinamento físico; Habilidades motoras; Criança.

\section{RESUMEN}

Introducción: Las habilidades motoras finas son importantes para los niños, no solo en las actividades de la vida diaria, sino también en las actividades de aprendizaje. En el presente estudio, los efectos de entrenamiento físico supervisado fueron investigados en niños. Objetivo: Evaluar los efectos del entrenamiento supervisado, combinando el ejercicio de cuerpo entero y las actividades de coordinación ojo-mano para mejorar las habilidades motoras finas en un grupo de niños normales de cinco años deedad. Métodos: Cincuenta y dos niños fueron seleccionados y asignados aleatoriamenteen grupos ejercicio y control. El grupo ejercicio participó en tres sesiones de entrenamiento de 30 minutos por semana durante 24 semanas. Resultados: Las habilidades motoras finas y la fuerza prensil manual del grupo ejercicio aumentaron significativamente, mientras que no hubo alteración significativa en el grupo control durante el período experimental. Conclusión: Los resultados indican que el programa de entrenamiento actual es efectivo y puede ser aplicado a niños normales de cinco años de edad para mejorar sus habilidades motoras finas. Además, este programa tiene actividades físicas simples que son adecuadas al nivel físico y mental de desarrollo infantil. La sesión de 30 minutos sería fácilmente implementada en el programa del jardín de infancia. Nivel de Evidencia l; Estudio clínico aleatorio de alta calidad, con o sin diferencia estadísticamente significativa, pero con estrechos intervalos de confianza.

Descriptores: Entrenamiento físico; Habilidades motoras; Niño. 


\section{INTRODUCTION}

Fine motor skills are referred to the capacity to use the small muscles in the hands, fingers, and wrists to perform delicate motor activities, with the coordination of visual perception. 'The skills are important to children not only for their daily living (for example holding small items, buttoning clothing, and eating), but also for their learning activities (such as writing, drawing, and using computer keyboard). Fine motor skills influence math and written expression, ${ }^{1}$ perceived scholastic competence, ${ }^{2}$ early numeracy performance, ${ }^{3}$ kindergarten student attention and achievement, ${ }^{4,5}$ and daily physical activity level. ${ }^{6}$ Poor fine motor skills have been found in children with developmental coordination disorder, ${ }^{2,7}$ hemiplegic cerebral palsy, ${ }^{8}$ and obesity. ${ }^{9,10}$ When considered the developmental aspect of fine motor skills, one study has demonstrated that poor fine motor skills at five years old might result in a delayed motor development at 15 years old. ${ }^{7}$ Based on these evidences, it is reasonable to deduce that high fine motor skills at early ages would benefit children's learning and scholastic performance, as well as their daily living ability.

Various treatments have been attempted to enhance fine motor skills. ${ }^{11-13}$ In the present study, we consider the fine motor skills as one of the general functional capacities. Increasing the level of fine motor skills at early ages is also important for children with a typical development. Therefore, we focused our attention to the effects of exercise training on fine motor skills in normal children.

In the literature, there are few studies about the improvement of fine motor skills through physical exercise training in children. Brown carried out an interventional study in 5-6-year-old normal children. ${ }^{14}$ While singing and following the rhyme of the action-type songs, children were trained basic hand movement 15 minutes per day for five months. Their fine motor skill, measured by a copying fine motor activity, was developed much faster than those of the non-exercise control group. Bhatia et al. trained a group of 5-year-old normal children by the Montessori educational gymnastics on fine motor development of young children. ${ }^{15}$ After eight months of treatment, the trained children significantly increased the accuracy and speed of a flag posting test, compared to the performance of the control group. A recent cross-sectional study has also reported that preschool children who engaged in more fine motor playing activities at home (data collected by a parent questionnaire) had greater fine motor skills. ${ }^{16}$ The results from these previous studies imply that various training programs of hand movement can enhance fine motor skills specially. To enrich the possibility of exercise training programs suitable for the development of children's fine motor skills, we have been working on to design an outdoor and whole body exercise program. This kind of exercise program has been reported to improve health condition in preschool children. ${ }^{17,18}$ Following the definition of fine motor skills, we designed an exercise program which combined whole body exercise and the eye-hand coordinative movement. The training target was the conjoined action of hand, eye, and body of the children. The purpose of the present study was to investigate the effect of 24 weeks of this specially designed exercise training on fine motor skills, visual response, and muscular strength in 5-year-old normal children. We tested the hypothesis that this exercise training program would improve the fine motor skills of children, compared to the outcome from non-exercise control group.

\section{METHODS}

All of 5-year-old children in a kindergarten in Tianjin city, China, were interviewed. The children who had heart diseases, pulmonary diseases, and any physical limitations to exercise were excluded. 52 children were suitable to the recruiting criteria and took part in this study. The exact details of the study were explained to the parents and teachers before the baseline test. The written informed consent was signed by the parent of each child. This study was approved by the Ethics Committee of Tianjin University of Sport, China (ID: BLA140067).

After the baseline tests, the enrolled children were randomly allocated into the exercise and control groups, $n=26$ in each. The exercise group was trained three 30-minute sessions per week for 24 weeks. The control group kept their habitual physical activity level during the experimental period. Fine motor skills, visual response, and muscular strength were measured before and after the interventions. For each test, the same researcher performed the tests of pre- and post-treatment in the same testing environment. The test-retest reliability of fine motor skills and visual response test were examined in 15 children (from these 52 children) before baseline measurements. All of tests and training sessions were carried out in the playground and the medical room of the kindergarten. The training sessions were supervised by the researchers and teachers, with a ratio of supervisor to children 1: 6 .

Body mass was assessed with a balance scale and body height was measured with a stadiometer (without shoes). Body mass index (BMI) was calculated by dividing body mass $(\mathrm{kg})$ by height in meters squared $\left(\mathrm{m}^{2}\right)$.

There were six tests which required the ability of fine muscle control and visual-motor coordination. Children received the detailed instruction of how to perform the test and practised the test once beforehand. The real test was done after three minutes of break.

Placing pegs: on a pegboard with 100 holes ( 10 holes per row $\times 10$ columns) of $1.6 \mathrm{~mm}$ in diameter, separated by $20 \mathrm{~mm}$ around. The child inserted the metal sticks (1.5 mm in diameter and $20 \mathrm{~mm}$ in length) into the holes column by column as fast as possible with the dominate hand. The number of inserted sticks in one minute was recorded.

Turning buttons: 32 plastic buttons $(35 \mathrm{~mm}$ in diameter and $15 \mathrm{~mm}$ in height) have red colour on one side and black on another side. All buttons were put on a board with the red side up. The child turned them to the black side as fast as possible with the dominate hand. The time used was recorded.

Threading beads: both hands working together, the child was asked to thread 10 beads $(10 \mathrm{~mm}$ in outside diameter and $2.5 \mathrm{~mm}$ in diameter of the hole) onto a $20 \mathrm{~cm}$ string as fast as possible. The time used was recorded.

Curved track test: there was a curved track on a metal board, the widest part was $10 \mathrm{~mm}$ and the narrowest $2.2 \mathrm{~mm}$. The child held a metal pen $(1.5 \mathrm{~mm}$ in diameter) in the dominate hand and traced the pen along the track as fast as possible, but tried the best not to touch the edges. The metal board (equipment) can record the time to cover the track and the number of edge-touches automatically. The time and the number of edge-touches were used to calculate the hand stability index. A lower index means better performance of this test.

Transferring bean: using a pair of wooden chopsticks with the dominate hand, the child moved 10 broad beans from one cup to another (10 cm apart) as fast as possible. The time used was recorded.

Speed tapping test: the child was asked to tap on two square metal boards $(6 \mathrm{~cm} \times 6 \mathrm{~cm}$, separated by $40 \mathrm{~cm})$ in turn as fast as possible. Record the number the child tapped with the dominate hand in 30 seconds.

\section{Muscular strength}

After a warm-up period of muscle movements, hand grip strength was measured by the WCS-100 hand-grip dynamometer (Kaineng Company, Shandong, China) for both hands. Two trials for each hand were done and the better result was recorded, then the average of both hands was reported. Another test was throwing a tennis ball, three trials were done and the longest distance was reported. 
Exercise group had three 30-minute training sessions per week for six months. Following activities were completed in each session:

Warm-up period: walking and jogging, as well as muscle stretches for three minutes.

10-meter running $\times 2$ times: running while holding a soccer ball by both hands. This activity requested children using their fingers to hold the ball as running and keeping body balance.

Crawling through a 10-meter net tunnel $\times 2$ times. In this activity, children had to grip the unstable strings by hands to keep body balance when crawling. The eye, hand, and body movement were combined in this activity.

Finger exercise: finger flexion and extension and thumb do opposition to touch the tips of other fingers. This was a special activity for the finger and hand dexterity.

Squeezing rubber rings: 10 times per set $x 2$ sets for both hands. The harder rings were used as the muscle strength improved. This activity aimed to increase hand muscle strength.

Throwing sand bags: threw 10 small sand bags into a target at five meters away. This activity needed the cooperated exercise of eye and arm/hand muscles.

Balance beam walk: 3 meters long, $10 \mathrm{~cm}$ wide, and $15 \mathrm{~cm}$ high from ground. Walked twice. This activity trained children's combined ability of eye and muscle movement.

Pushing a tyre: pushed a tyre $(33 \mathrm{~cm}$ in diameter and $16 \mathrm{~cm}$ in width) 10 meters $\times 2$ times. Children used their arm/hand muscles to control the tyre when running, this activity trained their combined ability of eye and arm/hand muscle during movement.

Cool-down period: walking slowly and relaxing muscles for three minutes.

\section{Statistical analyses}

All the values were presented as Mean \pm SD. Baseline comparison between the exercise and control groups was done by the independent samples t-test. The test-retest reliability of fine motor skill measurements was calculated and assessed by the intraclass correlation coefficient (ICC) values. Effects of the interventions were tested by 2 times (before and after) $\times 2$ groups (exercise and control) factorial design, split plot analysis of variance (SPANOVA). Statistical significance was set at $p<0.05$. All analyses were performed using the SPSS Version 21 for Windows (SPSS Inc. Chicago, IL, USA).

\section{RESULTS}

During 24 weeks of intervention, one child of the exercise group moved away from that kindergarten. Four children of the control group did not complete the study (two moved away and two missed the post-tests). As a result, there were 25 children in the exercise group and 22 children in the control group. Their base-line characteristics were presented in Table 1 and did not have any differences in age, body mass, height, and BMI between the groups. In addition, we did not find significant difference in the measured variables between boys and girls, thus the combined data are reported in the present study. The test-retest reliability of six fine motor skills and visual response test showed the ICC values between 0.87 to 0.93 (placing pegs 0.87 ; turning buttons 0.92; threading beads 0.90; hand stability index 0.89; bean transferring test 0.89; and tapping test 0.93). There were no sport injuries occurred during exercise training.

Effects of exercise training and non-exercise control on fine motor skills and muscular strength were shown in Table 2 . The average training session attendance of the exercise group children was higher than 90\%. The hand dexterity variables of the exercise group were improved significantly. The trained children could place more pegs into the holes of the board $(p<0.01)$ and took much less time to turn 32 plastic buttons
Table 1. Characteristics of the children at baseline.

\begin{tabular}{c|c|c}
\hline Variables & Exercise $(\mathbf{n}=\mathbf{2 5})$ & Control $(\mathbf{n}=\mathbf{2 2})$ \\
\hline Age (years) & $5.5 \pm 0.3$ & $5.5 \pm 0.4$ \\
\hline Body mass $(\mathrm{kg})$ & $21.3 \pm 3.4$ & $20.6 \pm 2.7$ \\
\hline Height $(\mathrm{cm})$ & $116 \pm 5$ & $115 \pm 5$ \\
\hline Body Mass Index $\left(\mathrm{kg} / \mathrm{m}^{2}\right)$ & $15.7 \pm 1.7$ & $15.6 \pm 1.1$ \\
\hline Boys/Girls & $14 / 11$ & $10 / 12$ \\
\hline
\end{tabular}

Note: All data are presented in mean \pm SD.

Table 2. Changes in fine motor skills, visual response, and muscular strength after interventions.

\begin{tabular}{c|c|c|c|c|c}
\hline & \multicolumn{2}{|c|}{ Exercise $(\mathbf{n}=\mathbf{2 5})$} & \multicolumn{2}{c|}{ Control $(\mathbf{n}=\mathbf{2 2})$} & \\
\hline Variables & Before & After & Before & After & $\begin{array}{c}\text { P for } \\
\text { time* group }\end{array}$ \\
\hline $\begin{array}{c}\text { Placing pegs } \\
\text { (peg/min) }\end{array}$ & $14.8 \pm 2.1$ & $17.8 \pm 3.7^{* *}$ & $14.6 \pm 2.0$ & $15.2 \pm 1.8$ & 0.002 \\
\hline $\begin{array}{c}\text { Turning buttons (s) } \\
\text { Threading beads (s) }\end{array}$ & $41.3 \pm 12.0$ & $64.6 \pm 11.2^{*}$ & $71.8 \pm 9.5$ & $71.4 \pm 8.0$ & 0.023 \\
\hline Hand stability index & $0.99 \pm 0.49$ & $0.81 \pm 0.39$ & $0.97 \pm 0.38$ & $0.98 \pm 0.46$ & 0.104 \\
\hline Transferring bean (s) & $34.4 \pm 7.1$ & $30.9 \pm 4.2$ & $34.4 \pm 6.2$ & $32.1 \pm 6.1$ & 0.427 \\
\hline $\begin{array}{c}\text { 30-s speed tapping } \\
\text { (times) }\end{array}$ & $33.7 \pm 5.3$ & $37.3 \pm 4.7^{* * *}$ & $32.0 \pm 3.8$ & $31.6 \pm 3.9$ & 0.006 \\
\hline Hand grip (kg) & $7.1 \pm 1.9$ & $8.9 \pm 2.2^{*}$ & $7.1 \pm 2.0$ & $7.8 \pm 2.0$ & 0.015 \\
\hline $\begin{array}{c}\text { Throw a tennis ball } \\
(m)\end{array}$ & $5.4 \pm 0.9$ & $5.7 \pm 0.9$ & $5.3 \pm 1.1$ & $5.6 \pm 1.4$ & 0.857 \\
\hline
\end{tabular}

Note: All data are presented in mean \pm SD. P values are the 2-way ANOVA results of interaction between exercise and control (time*group). * $p<0.05 ;{ }^{* *} p<0.01$.

$(p<0.01)$ and thread 10 beads onto a spring $(p<0.05)$. Though the exercise group showed a trend of decreasing the hand stability index, this change was not significant when considered the result of the control group. The speed of transferring broad beans was not shown any difference between the groups. The exercise group had a significantly faster tapping speed than that of the control group $(p<0.01)$. The trained children had a significant increase in their hand grip strength $(p<0.05)$. The distances of throw a tennis ball were increased in both groups, but the main effect comparing between the groups was not significant.

\section{DISCUSSION}

As high fine motor skills may benefit children in their learning and daily living, ${ }^{4,6}$ intervention at early ages to achieve a high level of these skills should be considered by pre-school educators. ${ }^{19}$ To seek more possible methods for the development of children's fine motor skills, we designed an exercise training program with several physical activities focused on the eye-hand coordination. After 24 weeks of interventions, the main finding showed that the trained children achieved much better performance in 'placing pegs,', turning buttons', 'threading beads', and '30-s tapping test'; while, though the control group also showed better results, they did not make any statistically significant improvements in the measured variables. The results support the hypothesis of this study.

In the present study, two fine motor skill variables were not changed significantly after exercise training. The curved track test might need much ability of hand stability; however, it seemed that there were not enough practice on this aspect in the current training program. The performance of transferring beans did not show significant difference between the groups. A possible explanation for this issue may be the daily use of chopsticks in Chinese children. By the age of five, children have been learning to use chopsticks in eating, so the sensitivity of this test would be reduced in Chinese children. In addition, the performance of throwing tennis ball was increased in both groups. This activity requires more skeletal muscles of legs and trunk working together. This increase might be a result of natural growth. 
There are few studies about the improvement of fine motor skills through physical exercise training in children. A previous study reported the results of applying aerobic exercise to train fine motor skills in children aged nine years but they did not find significant improvement. ${ }^{20}$ There are some possible reasons would cause the non-significant change: the whole body movements, such as swimming and climbing, were played, but without a focus on the eye-hand coordination; the small sample size of $n=11$ in their study, which might have a poor statistical power; and one hour exercise training per week for 12 weeks might not produce enough physiological and mental stimuli to children's body. This outcome warrants further study of the association between fine motor skills and exercise training in children.

The current exercise program employs simple physical activities which are suitable to the physical and mental developing level of 5-year-old normal children. Kindergarten teachers can supervise the training sessions with a short induction. The equipment needed for this program are standard tools in kindergarten. The 30-minute training session should be easy to be integrated into the curriculum of kindergarten. These characteristics present a high educational value of this exercise training program.
There are some limitations in our study that should be addressed in future work. Only one age group of children was studied, the application of the present results is restricted to 5-year-old normal children. The present study did not test physiological and/or molecular changes in skeletal muscle and nervous system following the intervention, so we cannot explain the mechanism of the improved fine motor skills after exercise training. That would be a future study question of our research team.

\section{CONCLUSION}

The present study has contributed a specially designed exercise training program which can be used in 5-year-old normal children to help them improving fine motor skills effectively and safely.

\section{ACKNOWLEDGEMENTS}

This study was supported by The Chinese National Social Science Funds - Educational Science Project (BLA140067).

All authors declare no potential conflict of interest related to this article.

AUTHORS' CONTRIBUTIONS: Each author made significant individual contributions to this manuscript. YQ (0000-0003-2475-0327)* designed the study, analyzed the data, and reviewed the article; ST (0000-0002-1302-4306)*: designed the study, wrote and reviewed the article; MS (0000-0001-5096-2943)*: collected and analyzed the data and reviewed the article; JW (0000-0002-2012-5332)*: designed the study, analyzed the data, and wrote and reviewed the article. *ORCID (Open Researcher and Contributor ID).

\section{REFERENCES}

1. Carlson AG, Rowe E, Curby TW. Disentangling fine motor skills' relations to academic achievement: the relative contributions of visual-spatial integration and visual-motor coordination. J Genet Psychol. 2013;174(5-6):514-33.

2. Piek JP, Baynam GB, Barrett NC. The relationship between fine and gross motor ability, self-perceptions and self-worth in children and adolescents. Hum Movement Sci. 2006;25(1):65-75.

3. Van Rooijen M, Verhoeven L, Steenbergen B. Working memory and fine motor skills predict early numeracy performance of children with cerebral palsy. Child Neuropsychol. 2016;22(6):735-47.

4. Cameron CE, Brock LL, Murrah WM, Bell LH, Worzalla SL, Grissmer D, et al. Fine motor skills and executive function both contribute to kindergarten achievement. Child Dev. 2010;83(4):1229-44.

5. Stewart RA, Rule AC, Giordano DA. The effect of fine motor skill activities on kindergarten student attention. Early Child Educ J. 2007;35(2):103-9.

6. Wrotniak BH, Epstein LH, Dorn JM, Jones KE, Kondilisc VA. The relationship between motor proficiency and physical activity in children. Pediatrice. 2006;118(6):e1758-65.

7. Cantell MH, Smyth MM, Ahonen TP. Clumsiness in adolescence: educational, motor, and social outcomes of motor delay detected at 5 years. Adapt Phys Activ Q. 1994;1 1(2):115-29.

8. Tomhave WA, Van Heest AE, Bagley A, James MA. Affected and contralateral hand strength and dexterity measures in children with hemiplegic cerebral palsy. J Hand Surg Am. 2015;40(5):900-7

9. Gentier I, D'Hondt E, Shultz S, Deforche B, Augustijn M, Hoorne S, et al. Fine and gross motor skills differ between healthy-weight and obese children. Res Dev Disabil. 2013;34(11):4043-51.

10. Krombholz H. Motor and cognitive performance of overweight preschool children. Percept Mot Skills. 2013;116(1):40-57.
11. Case-Smith J. Effects of occupational therapy services on fine motor and functional performance in preschool children. Am J Occup Ther. 2000;54(4):372-80.

12. Hung YC, Casertano L, Hillman A, Gordon AM. The effect of intensive bimanual training on coordination of the hands in children with congenital hemiplegia. Res Dev Disabil. 2011;6(32):2724-31.

13. Reid D, Chiu T, Sinclair G, Wehrmann S, Naseer Z. Outcomes of an occupational therapy school-based consultation service for students with fine motor difficulties. Can J Occup Ther. 2006;73(4):215-24.

14. Brown CG. Improving fine motor skills in young children: an intervention study. Educ Psychol Pract. 2010;26(3):269-78.

15. Bhatia P, Davis A, Shamas-Brandt E. Educational gymnastics: the effectiveness of Montessori practical life activities in developing fine motor skills in kindergartners. Early Educ Dev. 2015;26(4):594-607.

16. Suggate S, Stoeger H, Pufke E. Relations between playing activities and fine motor development. Early Child Dev Care. 2016;187(8):1297-1310.

17. Martinez-Tellez B, Sanchez-Delgado G, Cadenas-Sanchez C, Mora-Gonzalez J, Martín-Matillas M, Löf $M$, et al. Health-related physical fitness is associated with total and central body fat in preschool children aged 3 to 5 years. Pediatr Obes. 2015;

18. Niederer I, Kriemler S, Zahner L, Bürgi F, Ebenegger V, Marques P, et al. BMl group-related differences in physical fitness and physical activity in preschool-age children: a cross-sectional analysis. Res $Q$ Exerc Sport. 2012;83(1):12-9.

19. Pirk JP, Dawson L, Smith LM, Gasson N. The role of early fine and gross motor development on later motor and cognitive ability. Hum Movement Sci. 2008;27(5):668-81.

20. Ziereis $S$, Jansen P. Effects of physical activity on executive function and motor performance in children with ADHD. Res Dev Disabil. 2015;38:181-91. 